
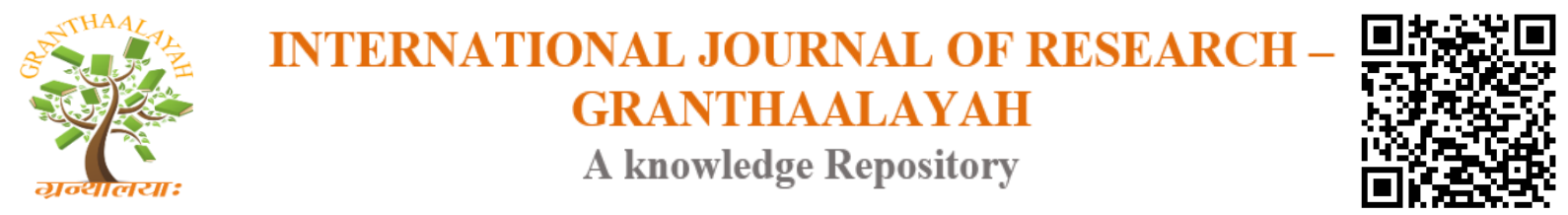

Management

\title{
CUSTOMER RETENTION: A STUDY ON INDIAN BANKS
}

\author{
Dr. S.N. Mahapatra ${ }^{1}$, Parveen Kumar ${ }^{2}$ \\ ${ }^{1}$ Associate Professor, Department of Management Studies, Deenbandhu Chhotu Ram University \\ of Science \& Technology, Murthal, Sonipat, Haryana, India \\ ${ }^{2}$ Research Scholar, Department of Management Studies, Deenbandhu Chhotu Ram University of \\ Science \& Technology, Murthal, Sonipat, Haryana, India
}

\begin{abstract}
The main purpose of this study is to examine how customer retention is affected by the factors of customer retention. A structured questionnaire was distributed to banking customers based on demographics (gender, age, marital status, education, occupation and, income level) in National Capital Territory. Data was successfully collected from 500 respondents who have either saving account or current account or both. Respondents' opinion on 20 items related to customer retention was obtained. Factors of customer retention were categorised into four main groups i.e. tangible, reliability, responsiveness and assurance \& empathy Factors. Further multipleregression analysis was used to measure the factors of customer retention and their impact on customers' retention decision. After multiple-regression it was found that 'Within Timeframe Service Delivery', 'Sincere Efforts in Solving Customer Problems' and 'Accepting \& Resolving Faults' are the most important factors which affect customers' retention intention.
\end{abstract}

Keywords: Customer Retention; Banking Customers; Service Delivery; Customer Problems.

Cite This Article: Dr. S.N. Mahapatra, and Parveen Kumar. (2017). "CUSTOMER RETENTION: A STUDY ON INDIAN BANKS." International Journal of Research - Granthaalayah, 5(7), 485-492. https://doi.org/10.29121/granthaalayah.v5.i7.2017.2157.

\section{Introduction}

India is second most populated country with seventh place in land holding in the world. Social, economic and geographic characteristics of India are different from that of other Asian countries which makes Indian banking sector unique as compared to its Asian counterparts. Customers are in better position to compare the services offered by different banks, if they get better services from competitor bank; they are prone to switch to other bank. Globalisation of banking sector has also added some fuel to this completion because with globalisation Indian banking sector is more open and exposed to the international competition. Now Indian banks are facing a great challenge to attain operational efficiency to sustain in the global competition. To face and counter the challenges caused by international and domestic banks and compete with international players Indian banks have to adopt a customer centric approach which should be 
mainly focused on building and deepening the relationship with their customers (Roy and Shekhar, 2010). The inevitable evolution of larger markets forced by competition has made the customer ultimate beneficiary and at the same time it has made it for banks to retain their customers in the process of market development (Vinita Kaura, 2013). Therefore, a significant improvement in profitability can be witnessed with a small reduction in the rate of customer defection. Firms gain not only financial benefits by retaining the customers, but they also get some non-financial benefits because satisfied and loyal customers will spread positive word-ofmouth publicity which further helps in attracting new customers.

To retain customers in service industry the organisations must be customer focus, which will improve service quality and consequently will be successful in retaining their customers. Establishing successful relationships plays a great role in improving organisation's performance by contributing considerably towards loyalty, and retention with customer satisfaction (Reichheld and Sasser, 1990; Rust and Zahorik, 1993). Behaviour and the level of motivation of staff also have some importance in respect to retention because satisfied employees tend to deliver better quality services. Effective internal marketing enhances the perception of employees regarding their role and responsibilities which in return assists in creating and maintaining a customer oriented service culture within the organisation.

\section{Literature Review}

Various studied have been conducted to know and explain the repurchase intentions of the customers. Customer retention has been described as customer's intention to stay with the particular service provider in future (Ranaweera et al, 2003). Some researchers argued that customer retention is the outcome of relational marketing efforts (Sheth and Parvatiyar, 2002; Manoj and Sunil, 2011; Jeng and Bailey, 2012). Payne and Frow (1999) suggested that existing and potential customer value should be considered as one of the criteria for market segmentation. It has been always argued that it cost more in acquiring a customer than retaining the existing ones (Reichheld and Kenny, 1990; Reichheld and Sasser, 1990).

Hennig (2000) developed a linear model to analyze customer retention and propounded that relationship quality is an important factor for retaining customers which lies between customer satisfaction and retention. Tamuliene et al. (2014) claimed that there is statistically proven significant positive relationship between customer satisfaction, relationship quality, switching costs and customer retention. Customer centric culture based on coordinated and integrated organisational structure is essential for successful customer retention. Lewington et al. (1996) considered information system as an essential support for customer retention efforts. It helps in maintaining the customers' purchase records, calculating the customer value and then focusing on likely defectors. Conventionally customer satisfaction has been considered as one of the essential determinant for long term customer relation. It is said that higher the number of satisfied customers, greater will be the retention (Anderson and Sullivan, 1993). Satisfied customers generate positive word of mouth (Reichheld and Sasser, 1990). Whereas Hart and Johnson, (1999) argued that trust is much important factor than satisfaction in retaining customers. Switching barrier is another factor in customer retention (Gremler and Brown, 1996; Bansal and Taylor, 1999). Higher switching barriers lead to higher rate of customer retention. Some other researchers established that service excellence forces customers to buy from again 
same service provider, make customers less price sensitive and spread positive word of mouth (Zeithaml et al., 1996; Bolton et al., 2000). Mahapatra and Kumar, (2017) provided that poor service quality and lack of commitment is one of the reason of customer dissolution.

\section{Research Objective}

Review of existing literature in the field of customer retention discloses that in past various studies have been conducted on customer retention and these studies given some factor affecting customer retention like service quality, reliability, Assurance, customer satisfaction, Relationship Quality, relationship trust, switching barrier, integrated organisational structure and customer centric culture etc. The main objective of this study to examine the various factors constituting customer retention and find out the most important factors affecting customer retention in Indian banking industry.

\section{Material and Methods}

To fulfill the research objective, descriptive research design was adopted as it was found suitable for the study. A questionnaire was designed to collect the data and find out the most important aspect of customer retention in banking industry. Questionnaire contains 20 items related to customer retention which are broadly divided into four groups i.e. Tangible, Reliability, Responsiveness and Assurance \& empathy Factors. The data was collected from 500 banking customers in National Capital Region. Customers were requested to give their opinion regarding the factors affecting customer retention on Likert's 5 point scale. Opinions were recorded from 'Strongly Disagree' to 'Strongly Agree' and weight 1 assigned to 'Strongly Disagree' and 5 to 'Strongly Agree'. Questionnaires were distributed at the bank premises and were Face-to-Face administered in order to maximize the response rate and solve the queries of the respondents.

Table 1: Demographic profile of the Respondents $(\mathrm{N}=500)$

\begin{tabular}{|c|c|c|c|c|c|}
\hline Gender & $\begin{array}{l}\text { Marital } \\
\text { Status }\end{array}$ & Age & Qualification & Occupation & $\begin{array}{l}\text { Monthly } \\
\text { Income }\end{array}$ \\
\hline $\begin{array}{l}\text { Male: } \\
60.40 \% \\
\text { Female: } \\
39.60 \%\end{array}$ & $\begin{array}{l}\text { Single: } \\
30.20 \% \\
\text { Married: } \\
68.40 \% \\
\text { Separated: } \\
1.40 \%\end{array}$ & $\begin{array}{l}\text { 20-30 Years: } \\
8.00 \% \\
\text { 30-40 Years: } \\
40.20 \% \\
\text { 40-50 Years: } \\
18.40 \% \\
\mathbf{5 0 - 6 0} \text { Years: } \\
10.60 \% \\
>\mathbf{6 0} \text { Years: } \\
2.80 \%\end{array}$ & $\begin{array}{l}\text { Upto Graduation: } \\
57.20 \% \\
\text { Above } \\
\text { Graduation: } \\
42.80 \%\end{array}$ & $\begin{array}{l}\text { Self } \\
\text { Employed: } \\
24.80 \% \\
\text { Government } \\
\text { Job: } \\
29.00 \% \\
\text { Private Job: } \\
32.80 \% \\
\text { Professionals: } \\
7.80 \% \\
\text { Unemployed: } \\
5.60 \%\end{array}$ & $\begin{array}{l}\text { < Rs. 30000: } \\
23.80 \% \\
\text { Rs. 30000- } \\
\text { Rs.80000: } \\
\text { 60.20\% } \\
\text { > Rs.80000: } \\
16.00\end{array}$ \\
\hline
\end{tabular}

Table 1 shows out of 500 customer surveyed male customers $(60.40 \%)$ are more than female customers (39.60\%). Most of the customers surveyed are married (68.40\%), followed by Single $(30.20 \%)$ and Separated $(1.40 \%) .57 .20 \%$ customers are having education qualification upto graduations and remaining $42.80 \%$ are above graduation. $24.80 \%$ are self-employed. Most of the 
customers are employed as $29.00 \%$ doing government jobs and $32.80 \%$ doing private job. Only $7.80 \%$ are professionals and remaining $5.60 \%$ are unemployed. Maximum respondents earn between Rs. 30000-Rs. 80000 .

\section{Results and Discussion}

Customer retention data was collected on 20 items related to customer retention which are broadly divided into four groups i.e. Tangible, Reliability, Responsiveness and Assurance \& empathy Factors. Overall Cronbach's Alpha is 0.897 which proves the reliability of the data collected. The interpretation of mean score and standard deviation (see table 3) suggests that 'Modern Equipment/Software' used by banks is most important tangible factor having mean value 3.87; Out of 5 reliability related factors 'Secrecy and Accuracy' (Mean: 4.22) is most important factor; 'Efficiency Service Delivery' (Mean: 4.09) is highest rated among responsiveness factors; and 'Feeling of Safety while Transacting' (Mean: 4.11) is an important assurance and empathy factor.

Table 2: Descriptive Statistics Regarding Customer Retention

\begin{tabular}{|c|c|c|c|c|c|c|c|c|c|c|}
\hline \multirow{2}{*}{ Factors } & \multicolumn{5}{|c|}{ Percentage } & \multirow{2}{*}{ Mean } & \multirow{2}{*}{$\begin{array}{l}\text { S. } \\
\text { E.M }\end{array}$} & \multirow{2}{*}{ S. D } & \multirow{2}{*}{\multicolumn{2}{|c|}{\begin{tabular}{|l|l|} 
Skew & Cronbach' \\
-ness & s Alpha
\end{tabular}}} \\
\hline & SD & D & $\mathbf{U}$ & $\mathbf{A}$ & $\mathbf{S A}$ & & & & & \\
\hline \multicolumn{11}{|l|}{ Tangible Factors } \\
\hline $\begin{array}{l}\text { Modern } \\
\text { Equipments/Software } \\
\end{array}$ & 4.00 & 6.80 & 13.20 & 50.00 & 26.00 & 3.87 & 0.04 & 1.00 & -1.09 & 0.89 \\
\hline $\begin{array}{l}\text { Visually appealing physical } \\
\text { facility }\end{array}$ & 2.00 & 15.20 & 26.40 & 42.80 & 13.60 & 3.51 & 0.04 & 0.97 & -0.40 & 0.89 \\
\hline $\begin{array}{l}\text { Dressing Sense and } \\
\text { Appearance of Staff }\end{array}$ & 5.80 & 14.80 & 32.40 & 38.80 & 8.20 & 3.29 & 0.04 & 1.00 & -0.46 & 0.90 \\
\hline $\begin{array}{l}\text { Visually Appealing } \\
\text { Material }\end{array}$ & 3.20 & 12.20 & 15.60 & 46.20 & 22.80 & 3.73 & 0.04 & 1.04 & -0.77 & 0.89 \\
\hline \multicolumn{11}{|l|}{ Reliability Factors } \\
\hline $\begin{array}{l}\text { Within Timeframe Service } \\
\text { Delivery }\end{array}$ & 2.60 & 8.60 & 8.20 & 44.80 & 35.80 & 4.03 & 0.04 & 1.01 & -1.16 & 0.89 \\
\hline $\begin{array}{l}\text { Sincere efforts in Solving } \\
\text { Problems }\end{array}$ & 2.60 & 5.80 & 12.80 & 43.60 & 35.20 & 4.03 & 0.04 & 0.97 & -1.12 & 0.89 \\
\hline Operational Accuracy & 2.20 & 3.20 & 13.00 & 46.40 & 35.20 & 4.09 & 0.04 & 0.89 & -1.19 & 0.89 \\
\hline Secrecy and Accuracy & 1.40 & 5.40 & 7.60 & 41.00 & 44.60 & 4.22 & 0.04 & 0.90 & -1.34 & 0.88 \\
\hline Help in Financial Planning & 1.00 & 5.00 & 17.60 & 48.80 & 27.60 & 3.97 & 0.03 & 0.86 & -0.79 & 0.89 \\
\hline \multicolumn{11}{|l|}{ Responsiveness Factors } \\
\hline $\begin{array}{l}\text { Prompt services delivery } \\
\text { and error correction }\end{array}$ & 1.60 & 7.60 & 11.00 & 53.40 & 26.40 & 3.95 & 0.04 & 0.90 & -1.04 & 0.88 \\
\hline $\begin{array}{l}\text { Responding customer } \\
\text { requests }\end{array}$ & 0.40 & 7.40 & 12.20 & 46.20 & 33.80 & 4.06 & 0.04 & 0.88 & -0.88 & 0.89 \\
\hline $\begin{array}{l}\text { Responding customers' } \\
\text { correspondence }\end{array}$ & 1.00 & 7.60 & 15.00 & 44.40 & 32.00 & 3.99 & 0.04 & 0.93 & -0.84 & 0.88 \\
\hline Efficiency Service Delivery & $y 2.20$ & 3.20 & 11.20 & 50.00 & 33.40 & 4.09 & 0.03 & 0.87 & -1.26 & 0.88 \\
\hline \multicolumn{11}{|c|}{ Assurance \& empathy Factors } \\
\hline
\end{tabular}




\begin{tabular}{|c|c|c|c|c|c|c|c|c|c|}
\hline $\begin{array}{l}\text { Knowledge and } \\
\text { Competency of Staff }\end{array}$ & 1.20 & 4.80 & 15.80 & 54.60 & 23.60 & 3.95 & 0.03 & 0.83 & -0.900 .89 \\
\hline $\begin{array}{l}\text { Feeling of Safety while } \\
\text { Transacting }\end{array}$ & 1.20 & 4.20 & 11.40 & 49.00 & 34.20 & 4.11 & 0.03 & 0.85 & $\begin{array}{ll}-1.09 & 0.89\end{array}$ \\
\hline $\begin{array}{l}\text { Feedback Guided } \\
\text { Behaviour }\end{array}$ & 2.00 & 6.20 & 16.00 & 47.20 & 28.60 & 3.94 & 0.04 & 0.93 & $\begin{array}{lll}-0.93 & 0.89\end{array}$ \\
\hline Personal Attention & 0.80 & 12.60 & 21.40 & 38.80 & 26.40 & 3.77 & 0.04 & 1.00 & -0.480 .89 \\
\hline $\begin{array}{l}\text { Understanding Specific } \\
\text { Needs }\end{array}$ & 1.80 & 8.20 & 14.60 & 47.80 & 27.60 & 3.91 & 0.04 & 0.95 & -0.900 .89 \\
\hline $\begin{array}{l}\text { Accepting and Resolving } \\
\text { Faults }\end{array}$ & 4.00 & 8.40 & 12.40 & 47.00 & 28.20 & 3.87 & 0.04 & 1.04 & $\begin{array}{ll}-1.03 & 0.89\end{array}$ \\
\hline Extending Banking Hours & 3.40 & 7.60 & 23.60 & 41.20 & 24.20 & 3.75 & 0.04 & 1.01 & -0.710 .89 \\
\hline
\end{tabular}

SD- Strongly Disagree, D- Disagree, U- Uncertain, A- Agree, SA- Strongly Agree, S.E.MStandard Error of Mean, S.D- Standard Deviation.

N: 500

Cronbach's Alpha: 0.897

Table 3: Multiple Regression Results regarding Consumer Retention

\begin{tabular}{|l|l|l|l|}
\hline Independent Variable & $\boldsymbol{\beta}$ Coefficients & t-Value & Significance \\
\hline Modern Equipments/Software & .021 & .372 & .710 \\
\hline Visually appealing physical facility & -.007 & -.123 & .902 \\
\hline Dressing Sense and Appearance of Staff & -.020 & -.414 & .679 \\
\hline Visually Appealing Material & .062 & 1.239 & .216 \\
\hline Within Timeframe Service Delivery & -.291 & -4.561 & .000 \\
\hline Sincere efforts in Solving Problems & .289 & 4.602 & .000 \\
\hline Operational Accuracy & -.004 & -.065 & .948 \\
\hline Secrecy and Accuracy & -.084 & -1.385 & .167 \\
\hline Help in Financial Planning & -.081 & -1.442 & .150 \\
\hline Prompt services delivery and error & .042 & .645 & .519 \\
correction & -.063 & -.988 & .323 \\
\hline Responding customer requests & -.113 & -1.878 & .061 \\
\hline Responding customers' correspondence & .103 & 1.584 & .114 \\
\hline Efficiency Service Delivery & .098 & 1.726 & .085 \\
\hline Knowledge and Competency of Staff & -.011 & -.182 & .856 \\
\hline Feeling of Safety while Transacting & .049 & .830 & .407 \\
\hline Feedback Guided Behaviour & .005 & .093 & .926 \\
\hline Personal Attention & .118 & 2.116 & .035 \\
\hline Understanding Specific Needs & -.188 & -3.036 & .003 \\
\hline Accepting and Resolving Faults & -.068 & -1.379 & .169 \\
\hline Extending Banking Hours & & & \\
\hline Sarn & & & \\
\hline
\end{tabular}

Sample $R^{2}=.115$

Adjusted $R^{2}=.078$

Overall Degree of Freedom $=499$

$F=3.104$

Number of Cases $=500$ 
In this study multiple-regression analysis was used to measure the factors of customer retention and their impact on customers' retention decision (See table 3). The regression analysis shows that $\mathrm{R}^{2}=0.115, \mathrm{~F}=3.104$ and $\mathrm{p}$-value $=0.000$. The value of $\mathrm{R}^{2}$ shows that there is 11.5 variance. It can be observed from the above table that 'Within Timeframe Service Delivery' ( $\mathrm{p}$-value=.001), 'Sincere Efforts in Solving Customer Problems' ( $p$-value=.001) and 'Accepting \& Resolving Faults' (p-value=.003) are the most important factors which affect customers retention in Indian banking industry. Previous studies on customer retention discloses various factors responsible for customer retention like customer satisfaction; relationship quality (Hennig); customer participation, relationship, satisfaction and quality (Zeithaml et al. 1996); customer satisfaction, relationship quality, switching costs (Tamuliene et al. 2014); trust (Hart and Johnson 1999); switching barrier (Gremler and Brown, 1996; Bansal and Taylor, 1999); customer participation, relationship, satisfaction and quality (Zeithaml et al. 1996).

\section{Conclusion and Recommendations}

In the era of cut throat competition it has become essential to retain the existing customer to succeed in the market. Customer centric approach is a prerequisite to retain the customers because customer centric organisations will focus on providing quality services and will deliver these services within time. Firms have to build a quality relationship with the customers to make them loyal to the organisation as emotional cost (switching barrier) is attached with it. Service providers must also focus on creating switching barrier to stop or reduce the defection of customer. Customer satisfaction should be given utmost importance as it is one of the most important variables impacting customer retention. It has always been claimed that customer retention efforts cost less to the organisation as compare to customer acquisition efforts. Reichheld \& Sasser, (1990) suggested that managers should shift their focus from prospective customers to retaining the existing customers through Customer Relationship management. The real focus remains on reducing defection of the profitable customer (Cao \& Gruca, 2005; Reinartz et al. 2005). Most importantly as per this study Indian banks should deliver services to the customers within the prescribed time, they should put sincere efforts in solving customers' problems and if there is any fault from bank side, they should accept it and try to correct the same.

\section{References}

[1] Anderson, E.W. \& Sullivan, M.W., The antecedents and consequences of customer satisfaction for firms", Marketing Science, 12 (2), 1993, 125-43.

[2] Anderson, E.W., Fornell, C. \& Lehmann, D.R., Customer satisfaction, market share, and profitability: findings from Sweden, Journal of Marketing, 58 (3), 1994, 53-66.

[3] Bansal, H.S. \& Taylor, S.F., The service provider switching model (SPSM): a model of consumer switching behaviour in the service industry, Journal of Service Research, 2 (2), 1999, 200-18.

[4] Bitner, M.J., Evaluating service encounters: the effects of physical surroundings and employee responses, Journal of Marketing, 54, 1990, 69-82.

[5] Bolton, R.N., Kannan, P.K. \& Bramlett, M.D., Implications of loyalty program membership and service experiences for customer retention and value, Journal of the Academy of Marketing Science, 28, 2000, 95-108.

[6] Borle, S., Boatwright, P., Kadane, J. B., Nunez, J. C. \& Shmueli, G., The effect of product assortment changes on customer retention, Marketing Science , 24 (4), Fall 2005, 616-622. 
[7] Dick, Alan S. \& Kunal Basu, Customer Loyalty: Toward an integrated conceptual framework, Journal of the Academy of Marketing Science, 22, Spring, 1994, 99-113.

[8] Farquhar, J.D., Retaining customers in UK financial services: The retailers' tale, The Service Industries Journal, 25(8), 2005, 1029-1044.

[9] Fornell, C., A national customer satisfaction barometer: the Swedish experience, Journal of Marketing, 56, 1992, 6-21.

[10] Gremler, D.D. \& Brown, S.W., Service loyalty: antecedents, components, and outcomes, American Marketing Association, Winter 1998, 165-166.

[11] Gustafsson, A., Johnson, M.D., \& Roos, I., The effects of customer satisfaction, relationship commitment dimensions, and triggers on customer retention, Journal of Marketing, 69, October 2005, 210-218.

[12] Hart, C.W. \& Johnson, M.D., Growing the trust relationship, Marketing Management, spring 1999, 8-19.

[13] Hennig-Thurau, T., Relationship Quality and Customer Retention through Strategic Communication of Customer Skills, Journal of Marketing Management, 16, 2000, 55-79.

[14] Jeng, D. J. \& Bailey, T., Assessing customer retention strategies in mobile telecommunications: Hybrid MCDM approach, Management Decision, 50, 2012, 1570 - 1595.

[15] Kaura, V., Antecedents of customer satisfaction: a study of Indian public and private sector banks, International Journal of Bank Marketing, 31 (3), 2013, 167-186.

[16] Lee, J. \& Feick, L., The impact of switching costs on the customer satisfaction-loyalty link: mobile phone service in France, Journal of Services Marketing, 15 (1), 2001, 35-48.

[17] Lemon, K. N., White, T. B., \& Russell S. Winer, Dynamic customer relationship management: Incorporating future considerations into the service retention decision, Journal of Marketing , 66, January 2002, 1-14.

[18] Lewington, J., de Chernatony, L. \& Brown, A., Harnessing the power of database marketing, Journal of Marketing Management, 12, 1996, 329-46.

[19] Liu, T. C. \& Wu, L.W., Customer retention and cross-buying in the banking industry: An integration of service attributes, satisfaction and trust, Journal of Financial Services Marketing, 12 (2), 2007, 132-145.

[20] Mahapatra, S.N. \& Kumar, P., Reasons why the customers dissolve their banking relationship from existing banks, International Journal of Research-Granthaalayah, 5 (6), 2017, 261-271

[21] Manoj, E. \& Sunil, S., Role of switching costs in the service quality, perceived value, customer satisfaction and customer retention linkage, Asia Pacific Journal of Marketing and Logistics, 23, 2011, $327-345$.

[22] Maute, M.F. \& Forrester Jr., W.R., "The structure and determinants of consumer complaint intentions and behavior, Journal of Economic Psychology, 14, 1993, 219-247.

[23] Payne, A. \& Frow, P., Developing a segmented service strategy, Journal of Marketing Management, 15, 1999, 797-818.

[24] Ranaweera, C. \& Prabhu, J., The influence of satisfaction, trust and switching barriers on customer retention in a continuous purchasing setting, International Journal of Service Industry Management, 14(4), 2003, 374-395.

[25] Reichheld, F.F. \& Kenny, D.W., The hidden advantages of customer retention, Journal of Retail Banking, 12 (4), 1990, 19-19.

[26] Reichheld, F.F. \& Sasser, W. E., Zero defections: Quality comes to services, Harvard Business Review, September/October, 1990, 105-111.

[27] Reinartz, W., Thomas, J. S. \& Kumar, V., Balancing Acquisition and Retention Resources to Maximize Customer Profitability, Journal of Marketing , 69, January 2005, 63-79.

[28] Roy, S. K., \& Shekhar, V., Dimensional hierarchy of trustworthiness of financial service providers, International Journal of Bank Marketing, 28 (1), 2010, 47-64.

[29] Rust, R. T., \& Zahorik A. J., Customer satisfaction, customer retention, and market share, International Journal of Retailing, 69 (2), 1993, 193-215. 
[30] Schneider, B. \& Bowen, D., Understanding customer delight and outrage, Sloan Management Review, 1999, 35-45.

[31] Sheth, J. N. \& Parvatiyar, A., Evolving relationship marketing into a discipline, Journal of Relationship Marketing, 1, 2002, 3-16.

[32] Tamulienea, V. \& Gabryte, I., Factors influencing customer retention: case study of Lithuanian mobile operators, Procedia - Social and Behavioral Sciences 156, 2014, 447 - 451.

[33] Wangenheim, F. V. \& Bayon, T., The chain from customer satisfaction via word-of-mouth referrals to new customer acquisition, Academy of Marketing Science, 35, 2007, 233-249.

[34] Verhoef, P. C., Understanding the Effect of Customer Relationship Management Efforts on Customer Retention and Customer Share Development, Journal of Marketing, 67, October 2003, $30-45$.

[35] Zeithaml, V. A., Berry, L.L. \& Parasuraman, A., The behavioral consequences of service quality, Journal of Marketing, 60 April 1996, 31-46.

[36] Zvirelieno, R. \& Buciuniene, I., The Role of Relationship Marketing Dimensions in the Customer Retention, Business: Theory and Practice, 9, 2008, 272 - 280.

*Corresponding author.

E-mail address: pkkalria@ gmail.com 